\title{
Source to sink dynamics in the Southern Neotethys: exemplified by a chemical study of Triassic-Miocene sandstones from Cyprus
}

\author{
G. CHEN $^{1 *}$, A. H. F. ROBERTSON ${ }^{2}$
}

${ }^{1}$ State Key Laboratory of Lithospheric Evolution, Institute of Geology and Geophysics, Chinese Academy of Sciences, P.O. Box 9825, Beijing 100029, China (*correspondence: Guohui.Chen@live.cn)

${ }^{2}$ School of GeoSciences, University of Edinburgh, West Mains Road, Edinburgh, EH9 3JW, UK

(Alastair.Robertson@ed.ac.uk)

Sandstone geochemistry provides useful clues concerning source-rock weathering, erosion, sedimentary transport, deposition, diagenesis and provenance. As an example, we use chemical data for sandstones from Triassic to Miocene passive and active margin settings from the Southern Neotethys in Cyprus, where facies, optical petrography, Xray mineralogy and other aspects are already extensively documented and interpreted. Late Triassic-early Cretaceous sandstones in southwest and southern Cyprus were ultimately derived from felsic-dominated source rocks (e.g., granodiorite) that became more weathered through time as conditions became more humid; sorting and recycling effects also increased over the same time interval. The sandstones were mainly recycled from Paleozoic siliciclastic shelf deposits in southern Turkey (Taurides) during the rift/passive margin development of the Southern Neotethys. For the late Cretaceous-late Miocene sandstones in northern Cyprus, the chemical signals are more complex and varied but can be interpreted in the context of facies, optical petrography and XRD data. Paleocurrent and other geological evidence support dominant supply from a mostly felsic continental source to the north (southern Turkey) during the late EoceneOligocene, with accumulation in an active margin setting related to northward subduction. Paleocurrent data then indicate westward supply, including mafic/ultramafic material from ophiolite-related rocks, during and after earlymiddle Miocene suturing of the Southern Neotethys in southeast Turkey. Overall, chemical composition was strongly influenced by inherited tectonic setting, especially late Precambrian-Cambrian Pan-African orogeny and subsequent Paleozoic continental shelf deposition. 